\title{
ANALISIS TINGKAT IMPLEMENTASI GOOD CORPORATE GOVERNANCE PADA USAHA KECIL DAN MENENGAH (UKM) DI KOTA PADANG
}

\author{
Hesty Aisyah* \\ STMIK Indonesia Padang, Indonesia
}

\begin{abstract}
Nowadays economic independence is one indicator in measuring the welfare of a country. Economic independence is made from the current country's economic system. An economic system is a systematic way in which a country distributes its resources. The better the system is implemented, the better the economic growth rate of the country will be. One things that mostly affect the rate of economic growth is the increasing number of Small and Medium Enterprises (SMEs). Therefore, the government has designed the program for SMEs which is not supported by Good Corporate Governance (GCG), which results in lack of integrations between the government program and the SME management system. The purpose of this study is to investigate aspects of the management arrangements of 150 SMEs in Padang, and also to identified all aspects which is need to be modified so that the Good Corporate Governance (GCG) system can be implemented on these SMEs. The survey results in this study found that the implementation of Good Corporate Governance in Padang City SMEs is still very limited, so this research still needs to be explored further to find the right Good Corporate Governance (GCG) patterns implemented for Padang's SMEs.
\end{abstract}

JEL : L26, O14.

Keywords : corporate governance, small and medium enterprises, economic industry.

\begin{abstract}
ABSTRAK
Saat ini kemandirian ekonomi merupakan salah satu indikator dalam mengukur kesejahteraan sebuah negara. Kemandirian ekonomi itu terletak dari bagaimana sistem ekonomi negara tersebut berjalan. Sistem ekonomi adalah sebuah cara sistematis di mana suatu negara dapat mendistribusikan sumber dayanya. Semakin baik sistem diterapkan, semakin baik tingkat pertumbuhan ekonomi negara itu. Salah satu hal yang paling mempengaruhi laju pertumbuhan ekonomi adalah meningkatnya jumlah Usaha Kecil dan Menengah (UKM). Oleh karena itu, pemerintah telah merancang beberapa program untuk UKM tapi sayangnya tidak didukung oleh praktik Good Corporate Governance (GCG), yang mengakibatkan kurangnya integrasi antara program pemerintah dan sistem manajemen UKM tersebut. Tujuan dari penelitian ini adalah untuk menyelidiki aspek pengaturan manajemen dari 150 UKM di Padang, dan juga untuk mengidentifikasi semua aspek yang perlu dimodifikasi sehingga sistem Good Corporate Governance (GCG) dapat diimplementasikan pada UKM ini. Hasil survei dalam penelitian ini menemukan bahwa penerapan Good Corporate Governance di UKM Kota Padang masih sangat terbatas, sehingga penelitian ini masih perlu dieksplorasi lebih lanjut untuk menemukan pola Good Corporate Governance (GCG) yang tepat diterapkan untuk UKM di Padang.
\end{abstract}

Kata Kunci : tata kelola perusahaan, usaha mikro kecil menengah, ekonomi industri.

\section{PENDAHULUAN}

Pertumbuhan ekonomi negara bisa dipengaruhi oleh beberapa hal, salah satunya adalah pertumbuhan Usaha Mikro, Kecil, dan Menengah (UMKM) di Indonesia. Dari keseluruhan jumlah

\footnotetext{
*Email : hestyaisyah@stmikindonesia.ac.id

Received : 05-08-2019, Accepted : 22-08-2019, Published : 28-04-2020.

P-ISSN : :2087-9954, E-ISSN : 2550-0066. DOI : http://dx.doi.org/10.26418/jebik.v9i1.34569
} 
perusahaan di Indonesia baik itu dari skala mikro sampai besar, 99,99\% merupakan total unit UMKM. Untuk sektor UMKM pada tahun 2017 sudah mempekerjakan tenaga kerja dengan persentase sebesar 97,02\% dari seluruh angkatan kerja (Dinas UMKM Sumbar, 2017). Pada tahun 2017, nilai keseluruhan ekspor yang telah disumbangkan oleh sektor UMKM telah mencapai 14\% dari keseluruhan ekspor non migas, dan menyokong Pendapatan Domestik Bruto (PDB) Indonesia atas dasar harga berlaku sebesar 60 \% (Dinas UMKM Sumbar, 2017). Data ini membuktikan bahwa sektor UKM sangat mempengaruhi gerak perekonomian nasional.

Peraturan pemerintah terkait dengan UMKM salah satunya tertuang pada Undang-undang nomor 20 tahun 2008 yang menyatakan bahwa maksimum total pendapatan sebesar Rp 50 Milyar pertahun serta kepemilikan aset sebesar Rp 10 Milyar dimana tidak termasuk tanah dan bangunan. Undang-undang ini ditujukan untuk mendapatkan kemudahan dalam mengklasifikasikan tingkatan dari setiap perusahaan yang ada di Indonesia. Dari hasil klasifikasi itu sendiri didapatkan bahwa UMKM merupakan sektor yang paling eksis di Indonesia dibandingkan dengan usaha skala besar. Untuk meningkatkan eksistensi sektor ini, maka setiap pihak baik dari lingkungan eksternal dan internal UKM tersebut harus meningkatkan kemampuan dan kemandirian manajerial.

Di masa yang akan datang, kemampuan dan kemandirian manajerial harus menjadi perhatian khusus untuk bisa menjamin keberlanjutan UKM. Salah satu hal yang bisa dilakukan untuk mencapai kemandirian dan keberhasilan manajerial ini adalah mengaplikasikan pedoman Good Corporate Governace (GCG) ke dalam sistem manajemen UKM tersebut. GCG didefinisikan sebagai sebuah konsep sistematika manajerial yang diperuntukkan penggunaanya kepada organisasi atau perusahaan yang telah memiliki struktur yang jelas dan sistem internal yang mumpuni, karena di dalam GCG terdapat asas yang berlaku bagi setiap skala bisnis, yaitu transparansi, akuntabilitas, tanggung jawab, independensi, dan kewajaran (Tjondro \& Wilopo, 2011). Asas ini merupakan acuan dan pedoman bagi semua UKM dalam mengembangkan usahanya.

Suatu perusahaan yang dikelola menggunakan sistem GCG dengan mengacu pada asasasas GCG akan membawa dampak lebih baik dibanding dengan perusahaan yang tidak memiliki tata kelola perusahaan dengan baik (Dwiridotjahjono, 2009). Kemudian disebutkan juga, perusahaan yang dikelola dengan baik akan memiliki kemampuan pengembalian pinjaman modal yang lebih cepat, meningkatkan kinerja produktivitas perusahaan secara signifikan, serta menambah nilai perusahaan di mata pasar dan investor baik di dalam maupun luar negeri (Dwiridotjahjono, 2009). Sedangkan menurut Forum for Corporate in Indonesia, salah satu manfaat dari adanya implementasi GCG dalam perusahaan adalah untuk memperbaiki kinerja usaha dan meningkatkan kinerja ekonomi sebuah perusahaan (FCGI, 2011).

Artikel ini memiliki beberapa tujuan penelitian, yaitu untuk menganalisa implementasi penerapan Good Corporate Governace di Kota Padang, sehingga bisa diketahui aspek-aspek pengaturan yang perlu dimodifikasi dari hasil identifikasi masalah penerapan GCG pada sektor UKM Kota Padang. Kota Padang dijadikan objek penelitian ini karena menurut data statistik, Kota Padang merupakan salah satu wilayah di indonesia dengan pertumbuhan UKM yang cukup signifikan. Sementara yang akan menjadi perumusan masalah dalam kajian ini yaitu: faktor-faktor apa saja yang menjadi indikator yang sangat mempengaruhi implementasi Good Corporate Governance (GCG) pada sektor UKM di Kota Padang. 


\section{KAJIAN LITERATUR}

Salah satu faktor yang bisa mendongkrak pertumbuhan ekonomi di sebuah daerah adalah kehadiran UMKM. Dengan adanya UMKM dengan jumlah yang banyak, maka akan membantu penyerapan tenaga kerja dan otomatis akan berpengaruh terhadap pendapatan ekonomi di daerah tersebut. Kota Padang merupakan kota pusat pemerintahan Provinsi Sumatera Barat, hal ini menjadikan kota ini sebagai salah satu kawasan dengan pertumbuhan bisnis yang pesat dibanding dengan kabupaten lainnya di Sumatera Barat. Bersumber dari data jumlah UMKM di Kota Padang tumbuh sebanyak 2.953 unit di tahun 2017, dengan total keseluruhan unit sampai saat ini adalah 81.182 UMKM.

Prinsip GCG dalam (Salim, 2018) antara lain:

a. Transparency (Keterbukaan), merupakan keterusterangan dalam hal pelaksanakan proses pengambilan keputusan dan juga dalam mengemukakan informasi terkait informasi yang relevan mengenai perusahaan.

b. Accountability (Akuntabilitas,) merupakan penggambaran sistem, fungsi, struktur dan pertanggungjawaban manajemen inti perusahaan agar terlaksana tata kelola perusahaan yang efektif.

c. Responsilbility (Pertanggungjawaban), merupakan kesesuaian atau kepatuhan pengelolaan perusahaan terhadap prinsip perusahaan yang sehat serta peraturan perundangan yang berlaku.

d. Independency (kemandirian), merupakan suatu keadaan dimana perusahaan dikelola secara profesional tanpa adanya konflik kepentingan dan pengaruh dari pihak manajemen yanga tidak sesuai dengan prinsip-prinsip korporasi yang sehat dan perundang-undangan yang berlaku.

e. Fairness (kewajaran dan kesetaraan), merupakan upaya memperlakukan pemangku kepentingan perusahaan dalam memenuhi hak-hak mereka dengan asas keadilan dan kesetaraan berdasarkan prinsip-prinsip korporasi yang sehat dan perundang-undangan yang berlaku.

Sistem Good Corporate Governance (GCG) di dalam sebuah perusahaan ditujukan untuk mengawasi dan menjamin berjalannya sistem governance dengan semestinya, mekanisme GCG pun diperuntukkan bagi perusahaan serta pihak-pihak yang terkait agar bisa terkendali dengan baik, sehingga menekan terjadinya masalah internal (Ntim, 2018). Beberapa penelitian menunjukkan bahwa dengan adanya mekanisme GCG ini, maka kinerja perusahaan akan berjalan searah dengan visi, misi, dan tujuan perusahaan tersebut, seperti penelitian yang dilakukan oleh Amoateng, et.al (2017) yang meneliti tentang dampak penerapan GCG pada sektor UMKM, dan ditemukan bahwa adanya GCG yangbai bisa meningkatkan pendapatan perusahaan tersebut. Ada juga hasil penelitian yang mengatakan bahwa mekanisme pengawasan corporate governance dibagi dalam dua kelompok diantaranya sistem internal dan eksternal. Sistem internal dalam bentuk rapat umum komposisi dewan komisaris, pertemuan dengan board of director, rapat pemegang saham, komposisi dewan direksi merupakan cara untuk mengendalikan perusahaan dengan menggunakan proses-proses di bagian internal perusahaan, sedangkan sistem eksternal merupakan pengendalian perusahaan dan mekanisme pasar dengan cara mempengaruhi perusahaan selain dengan menggunakan sistem internal (Fatimah, Mardani, \& Wahono, 2019). 
Ada beberapa faktor yang mempengaruhi mekanisme GCG pada sektor UMKM, diantaranya adalah: (1) Kebijakan pemerintah merupakan peraturan dari pemerintah terkait dengan prosedural kinerja sebuah perusahaan. Kebijakan mengenai GCG ini menyentuh semua unsur dalam sebuah perusahaan, agar pelaku UMKM bisa menjadikan kebijakan ini sebagai sebuah panduan dalam pelaksanaan GCG (Elmagrhi et al., 2017); (2) iklim yang dimiliki suatu perusahaan merupakan gambaran situasi dan suasana yang tercipta selama kegiatan perusahaan berlangsung. Semakin berkualitas iklim sebuah perusahaan, maka mekanisme GCG akan berjalan dengan baik (Kurniawati, Purnamasari, \& Puspitaningrum, 2015); (3) kemampuan kerja SDM merupakan gambaran keterampilan yang dimiliki oleh setiap SDM dalam menjalankan fungsinya masingmasing yang tertera dalam mekanisme GCG (Mailisa, Hendri, \& Fauzan, 2016); (4) bentuk kepemilikan usaha, merupakan bentuk persekutuan atau kerjasama yang dilakukan oleh beberapa orang dalam menjalankan bisnis tersebut. Kepemilikan usaha akan menentukan legalitas sebuah usaha. Semakin legal sebuah perusahaan, maka mekanisme GCG akan semakin berkualitas (Wardhana, 2018).

Seperti penjabaran diatas sebelumnya, perusahaan dengan skala kecil dan menengah (UKM) sangat cocok bila mengimplementasikan GCG dalam sistem manajemennya. Dalam pelaksanaannya, UKM cukup mengadopsi penerapan GCG yang diimplementasikan oleh perusahaan skala besar dengan mempertimbangkan hal-hal yang bernilai sederhana dan relevan untuk sektor UKM. Misalnya, UKM umumnya memiliki struktur manajemen yang masih tergolong tidak serumit sistem manajemen yang diimplementasikan usaha skala besar. Seperti, untuk pencatatan keuangan akuntabel yang dilakukan secara manual masih bisa dikerjakan oleh UKM karena tingkat kegiatan ekonomi UKM tidak sepadat kegiatan ekonomi usaha skala besar. Hanya yang perlu dipikirkan adalah bagaimana mengintegrasikan sistem manajemen yang sederhana tadi dengan sistem GCG yang diimplementasikan oleh usaha skala besar, agar sistem manajemen yang sederhana tadi bisa bernilai tinggi sehingga bisa mempengaruhi kualitas manajemen UKM.

Ada beberapa isu dalam pelaksanaan GCG di UKM berkaitan dengan permasalahan seperti: (1) bagaimana cara untuk menerapkan sistem keuangan yang sesuai standar sehingga menghasilkan pengelolaan perusahaan yang professional; (2) bagaimana cara agar operasional perusahaan bisa terintegrasi dengan sistem informasi yang canggih dan dikelola sendiri oleh manajemen perusahaan; (3) bagaimana menempatkan SDM yang efisien dan meningkatkan pengetahuan manajerial. Jawaban dari isu-isu diatas nanti akan bermuara pada tujuan penelitian yaitu menciptakan sistem manajemen. UKM inilah yang pada akhirnya bermuara pada terbangunnya konsep UKM yang accountable, reliable dan professional, dan transparan sesuai dengan tujuan dilaksanakannya GCG (Jaswadi, 2016).

Sebagaimana diuraikan sebelumnya sistem manajemen sederhana yang dilakukan UKM berdampak pada hal- hal yang substansial, seperti peminjaman modal pada bank. Pinjaman modal dari pihak perbankan atau leasing menjadi salah satu tujuan utama UKM sebagai tempat untuk meminjam sejumlah dana yang akan dijadikan modal usaha. Pencatatan keuangan yang masih tradisional karena kurangnya pemahaman tantang ilmu manajerial, lalu disertai dengan minimnya fasilitas menyebabkan sulitnya pihak peminjam modal mengakses informasi keuangan yang dimiliki oleh UKM. Cara tradisional yang masih diadopsi kebanyakan UKM akhirnya membuat pihak peminjam modal untuk menyalurkan dana pinjaman (Susilo, 2010). Pihak bank akan 
mempercayai sebuah perusahaan dengan skala apapun asalkan sudah memiliki laporan keuangan yang baik dan akuntabel.

Selain itu ada juga beberapa permasalahan yang umumnya dihadapi para pelaku UKM terkait dengan implementasi GCG tersebut antara lain: (1) strategi pemasaran; (2) informasi peraturan tata niaga impor; (3) ijin usaha; (4) sistem administrasi keuangan; (5) perolehan pinjaman dari Bank; (6) informasi peraturan tata niaga impor; (7) informasi pasar. Penerapan prinsip GCG pada UKM akan mendapatkan beberapa manfaat, diantaranya: (1) keberlanjutan pertumbuhan usaha; (2) mudahnya memperoleh pinjaman modal; (3) bisa menjangkau akses pasar nasional dan internasional. Manfaat-manfaat yang dipaparkan sebelumnya bisa menjadikan alasan yang kuat bahwa penerapan GCG harus segera dilakukan di lingkungan UKM agar iklim dunia usaha di Indonesia semakin membaik karena implementasi GCG sangat berpengaruh terhadap etika dalam menjalankan usaha dengan baik dan benar sesuai dengan asas GCG.

Implementasi GCG di Indonesia saat ini sudah meningkat cukup signifikan. Menurut data dari Asean Corporate Governance Scorecard (ACGS), Indonesia pada tahun 2017 sudah memiliki perangkat GCG yang cukup membaik seiring dengan peningkatan nilai dari 62,88 menjadi 70,59. Kemajuan ini disebabkan meningkatnya jumlah emiten atau Public Listed Company (PLC) yang berhasil masuk daftar top 50 ASEAN (Sukmadilaga, Pratama, \& Mulyani, 2015).

\section{METODE PENELITIAN}

Jenis penelitian explanatory dengan survey design akan menjadi metode penelitian ini. Dengan metode ini, akan mempermudah menganalisa studi kasus dan menarik kesimpulan dan opini dari jawaban permasalahan yang akan diuraikan sampel responden keseluruhan pelaku UKM di Kota Padang dari kuesioner yang akan diberikan (Wijaya \& Abdullah, 2016). Pelaku usaha yang usahanya dikategorikan usaha skala kecil sampai menengah dari berbagai sektor akan dijadikan objek pada penelitian ini. Kota padang dipilih karena Kota Padang merupakan saah satu kawasan yang pertumbuhan UKMnya cukup signifikan.

Keseluruhan total UKM yang memiliki produktivitas unggul yang berjumlah 2.276 unit dijadikan populasi dalam pengambilan sampel pada penelitian ini (Dinas UMKM Sumbar, 2017). Kemudian metode Purposive Random Sampling digunakan pada penelitian ini sebagai metode untuk pengambilan sampel. Metode ini menentukan pengambilan sampel dengan cara menetapkan ciri-ciri khusus sebagai sebuah pertimbangan yang sesuai dengan kriteria usaha dalam tujuan penelitian ini. Di antara ciri-ciri tersebut adalah perusahaan tersebut harus berskala kecil dan menengah yang terletak di Kota Padang dan sudah berproduksi lebih dari 10 tahun, karena dengan jangka waktu 10 tahun perusahaan tersebut bisa terus berproduksi berarti bisa diasumsikan perusahaan tersebut memiliki produkstivitas tinggi. Dengan metode tersebut diambil jumlah sampel secara acak sebesar 100 unit UKM.

Penelitian ini menggunakan instrumen penelitian dengan cara menyebarkan angket kepada responden. Instrumen penelitian dirancang sedemikian rupa dan dikembangkan berdasarkan kajian-kajian ilmiah yang pernah menerapkan pilar GCG sebelumnya (Department of Economic Development, 2013), karena panduan dari lembaga Dubai SME ini telah menjelaskan unsur dan kriteria dari GCG secara lengkap dan sistematis dibandingkan panduan yang sudah pernah ada sebelumnya. Sejumlah pertanyaan yang diberikan dalam bentuk kuesioner nantinya akan dijawab 
oleh para responden. Secara umum dari kuesioner bertujuan untuk memperoleh data-data kuantitatif tentang sistem manajemen UKM yang terintegrasi dengan implementasi GCG.

\section{HASIL DAN PEMBAHASAN}

\subsection{Informasi Umum Responden}

Penelitian ini menggunakan angket yang disebarkan kepada 100 pelaku UKM di Kota Padang sebagai responden melalui sistem offline (diberikan secara langsung) dan online (diberikan menggunakan aplikasi Google Form). Penelitian ini menerapkan metode non-probability purposive sampling dalam memilih responden dari keseluruhan jumlah Usaha Kecil, dan Menengah yang ada di Kota Padang. Dari 100 responden atau pelaku UKM yang sudah diberikan kuesioner, hanya sebanyak 33 responden yang telah mengirimkan jawaban. Berikut informasi umum yang diperoleh dari responden.

Pada Gambar 1 bisa dilihat bahwa sebagian besar dari responden adalah seorang manajer yang merangkap sebagai pengelola perusahaan (manager-owner) yaitu sebesar 70\%, sementara itu sisanya sebesar $30 \%$ responden hanya menjabat sebagai pelaksana perusahaan.

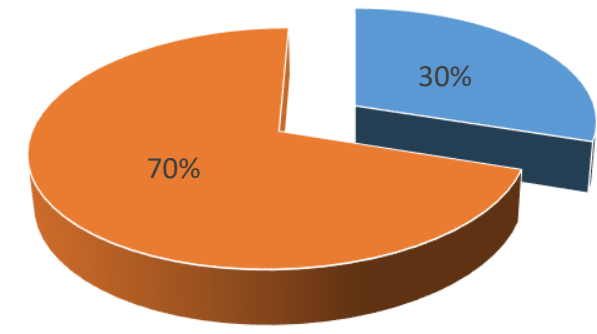

- Owner-Manager - Direktur/Manager

\section{Gambar 1. Posisi/ Jabatan Responden}

Gambar 2 menunjukkan jumlah dari sektor jenis apa usaha mereka dijalankan. Pelaku usaha dari sektor industri dan perdagangan memegang jumlah paling besar dari keseluruhan responden yaitu sebesar $45 \%$ untuk industri dan 33\% untuk perdagangan, kemudian disusul sektor perikanan sebesar $11 \%$ dan sektor lainnya. Hal ini sesuai dengan karakteristik Kota Padang yang dikenal sebagai sentra industri makanan dan perdagangan yang dipicu juga karena adanya pertumbuhan industri pariwisata.

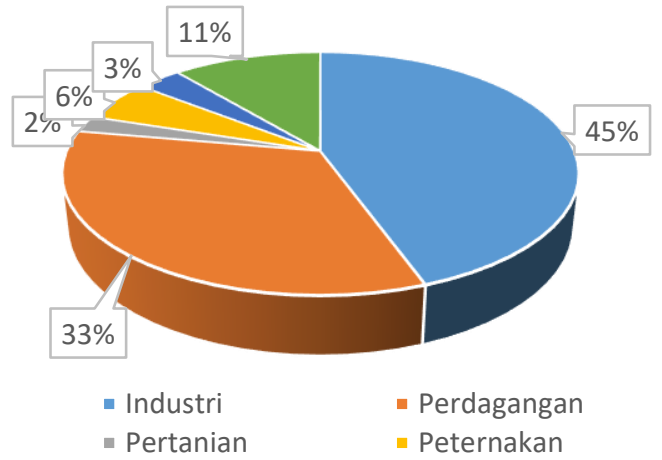

Gambar 2. Jenis Usaha Responden 
Penjelasan tentang status usaha responden bisa dilihat pada Gambar 3, dimana sebanyak $68 \%$ dari total responden status perusahaannya masih belum berbadan hukum.

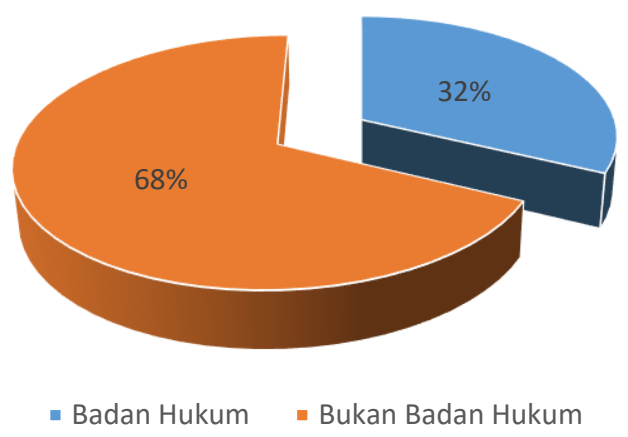

\section{Gambar 3. Status Usaha Responden}

Selanjutnya pada Gambar 4 menunjukkan proses sebuah usaha pada peredaran suatu bisnis, dimana proses masih dalam tahap pertumbuhan masih dialami oleh sebagian besar responden sebesar 38\%. Dari data tersebut didapat bahwa rata-rata industri makanan dan minuman dan perdagangan sedang dalam fase pertumbuhan, selebihnya responden masih berpersepsi bahwa usaha mereka masih dalam fase ekspansi dan juga matang.

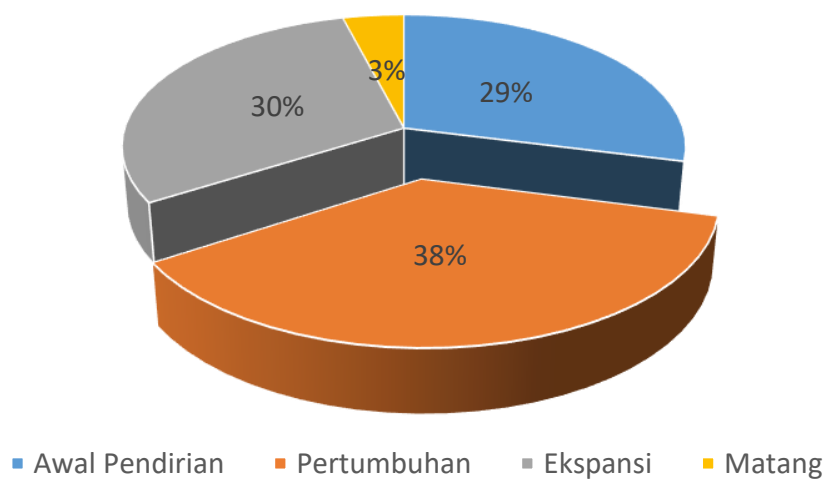

Gambar 4. Tahapan Siklus Bisnis Responden

Kemudian pada Gambar 5, memperlihatkan total pendapatan per tahun dari UKM Kota Padang sebesar kurang dari 300 juta rupiah sudah dimiliki oleh responden sebesar $7 \%$. Berpedoman pada peraturan tentang UMKM yang tertuang pada UU Nomor 20 tahun 2008 dinyatakan jika sebagian besar usaha skala menengah sudah mencapai estimasi penjualan perbulan diatas 100 juta rupiah atau lebih dari 2,5 milyar rupiah pertahunnya. Selebihnya berasal dari usaha kecil, dengan capaian omset antara 300 juta rupiah sampai dengan 2,5 Milyar rupiah. 


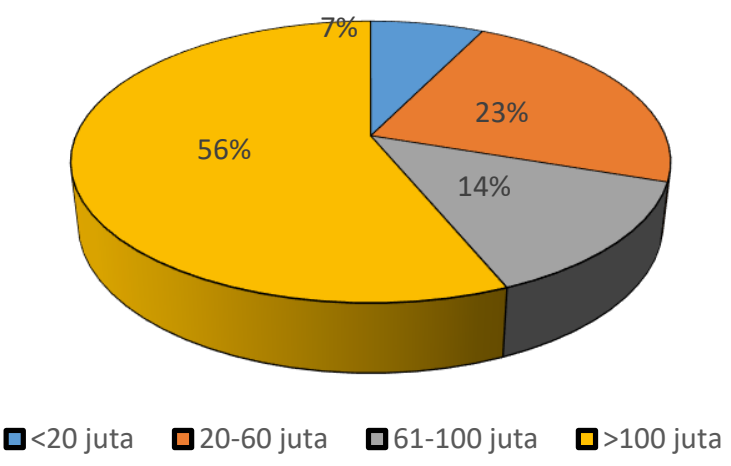

Gambar 5. Penjualan per Bulan

Gambar 6 menjelaskan rata-rata aset yang berupa peralatan dan mesin operasional perusahaan, dimana sebagian besar perusahaan memiliki nilai aset berupa mesin dan peralatan diatas Rp 150 juta dengan persentase $46 \%$.

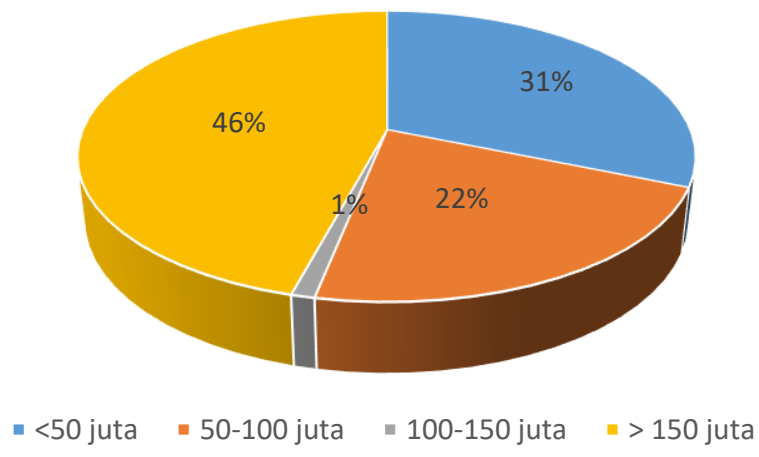

Gambar 6. Nilai Mesin dan Peralatan

\subsection{Tingkat Implementasi Good Corporate Governance pada UKM}

Berikut pada Tabel 1 adalah hasil uji statistik deskriptif mengenai tingkat implementasi GCG di UKM Kota Padang yang ditujukan untuk analisis awal pada penelitian ini.

Tabel 1. Statistik Deskriptif

Tingkat Implementasi Good Corporate Governance pada UKM

\begin{tabular}{|c|c|c|c|c|}
\hline Butir-Butir Pertanyaan & Mean & SD & Min & Max \\
\hline \multicolumn{5}{|l|}{$\begin{array}{l}\text { Pilar 1. Membuat kerangka mekanisme Corporate } \\
\text { Governance } \text { secara formal }\end{array}$} \\
\hline $\begin{array}{l}\text { Kejelasan pembagian hak dan kewajiban bagi } \\
\text { pemilik usaha }\end{array}$ & 3,86 & 1,11 & 1 & 5 \\
\hline $\begin{array}{l}\text { Peresmian kepemilikan tertuang secara resmi dalam } \\
\text { sebuah dokumen }\end{array}$ & 3,86 & 1,11 & 1 & 5 \\
\hline Kuantitas rapat manajemen pertahun & 1,57 & 0,94 & 1 & 4 \\
\hline Proses monitoring pemilik kepada pelaksana & 1,86 & 1,06 & 1 & 4 \\
\hline
\end{tabular}




\section{Pilar 2. Pimpinan perusahaan menyelenggarakan kegiatan perencanaan suksesi terhadap keberlanjutan pimpinan}

a. Perencanaan harus sesuai dengan visi misi yang dimiliki perusahaan

b. Perencanaan harus sudah melingkupi tentang metode yang digunakan untuk proses pergantian pimpinan

c. Adanya penerapan strategi exit yang dijalankan tiap pimpinan perusahaan

$\begin{array}{llll}3,80 & 0,62 & 2 & 5 \\ 3,23 & 1,05 & 2 & 5 \\ 2,30 & 0,85 & 1 & 3\end{array}$

Pilar 3. Membuat pola informasi yang transparan, terbuka, dan tepat waktu

a. Perlakuan yang adil diterima oleh seluruh pemegang saham dan perusahaan menyediakan media untuk berkomunikasi dengan dengan pemilik saham

b. Terdapat sebuah mekanisme produktif yang tertuang dalam RUPS

c. Adanya laporan mengenai kepemilikan keuangan dari setiap pemilik pertahun

d. Adanya laporan keuangan yang lengkap dan sistematis

Pilar 4. Memiliki kesungguhan dalam berupaya untuk membentuk Dewan Komisaris

a. Dewan Penasehat dapat dibentuk oleh perusahaan dengan ukuran lebih kecil dapat untuk mendukung perkembangan bisnis

b. Dewan Komisaris dibentuk melalui prosedur formal

c. Pihak independen seharusnya diajak oleh perusahaan sebagai anggota Dewan Komisaris tetap

d. Program pelatihan harus diberikan kepada anggotaanggota direksi yang baru

Pilar 5. Memberikan arahan secara sistematis tentang kontrol kinerja kepada kepada Dewan Komisaris

Dewan Komisaris harus mempunyai dukungan dalam menjalankan tugas utama

b. Dewan Komisaris melakukan kegiatan monitoring dan evaluasi terhadap kinerja manajemen

c. Evaluasi kinerja dilakukan secara rutin oleh Dewan Komisaris

d. Dewan Penasehat tidak merangkap jabatan operasional dalam perusahaan

Pilar 6. Auditor eksternal melakukan kewajibannya yaitu mengaudit pembukuan

a. Adanya praktik akuntan yang kredibel di dalam perusahaan.

b. Perusahaan menjaga independensi fungsi audit dan mengevaluasi efektifitas audit eksternal

Pilar 7. Pengendalian lingkungan internal dan kegiatan evaluasi ditetapkan secara resmi dalam sebuah standar perusahaan

a. Identifikasi resiko harus dilakukan secara berklaa oleh perusahaan

b. Dalam skala besar, perusahaan sudah bisa melaksanakan kegiatan pengendalian dalam cakupan yang besar

c. Perusahaan melakukan audit internal secara berkala

$\begin{array}{llll}4,15 & 0,36 & 4 & 5 \\ 4,05 & 0,92 & 2 & 5 \\ 3,88 & 0,33 & 3 & 4\end{array}$


Pilar 8. Mengenali kebutuhan pemangku kepentingan

a. Dalam proses pengambilan keputusan, semua pemangku kepentingan harus mengambil peran demi keberlanjutan perusahaan

b. Hubungan antara pemangku kepentingan harus punya indikator jelas yang bisa diukur dan dimonitor

\begin{tabular}{|c|c|c|}
\hline 4,05 & 0,86 & 2 \\
\hline 4,00 & 0,00 & 2 \\
\hline
\end{tabular}

5

5

Pilar 9. Formulasi kerangka yang menjelaskan hubungan keluarga dan bisnis

a. Perusahaan memiliki aturan dan kebijakan terkait tentang keluarga

b. Perusahaan memiliki tata kelola keluarga untuk memfasilitasi komunikasi.

$\begin{array}{llll}3,50 & 0,77 & 1 & 4 \\ 3,45 & 0,68 & 2 & 4\end{array}$

Dalam mengimplementasi sebuah sistem GCG, perusahaan seharusnya mengadopsi sebuah kerangka GCG secara formal yang mengatur peran inti perusahaan. Dalam menjalankan prosedur dan kebijakan tersebut, sebuah perusahaan skala UKM seharusnya melakukan kegiatan perencanaan suksesi (pergantian pimpinan) dengan tujuan untuk keberlanjutan hidup perusahaan tersebut. Untuk menilai apakah prosedur dan kebijakan GCG terlaksana dengan baik, maka para responden diminta untuk memberikan: (1) persetujuan atas tahapan dalam rangka mengadopsi kerangka tata kelola secara formal, dan (2) skema pendelegasian wewenang perusahaan kepada manajemen. Selanjutnya ada pertanyaan terkait untuk mengetahui bagaimana kedua tahapan tersebut dilaksanakan di perusahaan. Berikut Tabel 2 menjelaskan persetujuan dan persepsi atas prosedur dan kebijakan GCG.

Tabel 2. Persepsi Responden terhadap Prosedur dan Kebijakan GCG

\begin{tabular}{llc}
\hline Pilar 1. Membuat kerangka mekanisme Corporate Governance secara formal & Persetujuan (\%) \\
\hline a. & Kejelasan pembagian hak dan kewajiban bagi pemilik usaha. & 79,6 \\
b. & Peresmian kepemilikan tertuang secara resmi dalam sebuah dokumen. & 79,6 \\
c. & Kuantitas rapat manajemen pertahun & 80,2 \\
d. & Proses monitoring pemilik kepada pelaksana & 78,7
\end{tabular}

Pilar 2. Adanya kegiatan proses perencanaan suksesi terhadap pimpinan perusahaan

a. Perencanaan harus sesuai dengan visi misi yang dimiliki perusahaan $\quad 79,8$

b. Perencanaan harus sudah melingkupi tentang metode yang digunakan untuk $\quad 66,2$ proses pergantian pimpinan

c. Adanya penerapan Strategi Exit yang dijalankan tiap pimpinan perusahaan $\quad 80,2$

Sumber: Data diolah, 2019

Berdasarkan Tabel 2, responden memberikan pilar 1 tentang aspek kerangka formal atas mekanisme yang mengatur hak dan kewajiban para pemegang saham dengan tingkat kepentingan yang besar. Pilar 1 menggambarkan pentingnya cara menentukan keputusan oleh pemegang saham, manajemen puncak secara formal dituliskan dalam sebuah dokumen pada mekanisme GCG. Selanjutnya, pendelegasian wewenang kepada manajemen dibawah pimpinan Dewan Komisaris juga harus ditulis secara formal dan dievaluasi secara teratur agar sinkron dengan pertumbuhan perusahaan tersebut.Pada pilar 2 mengenai perencanaan suksesi yang terkait dengan pergantian pimpinan, responden memberikan peringkat penting pada tahap perencanaan daripada pergantian pimpinan yang dilakukan secara matang. Hal ini disebabkan karena sebagian besar responden adalah berstatus sebagai owner-manager dari seluruh responden. 
Untuk mengetahui sejauh apa transparansi dilakukan oleh UKM, responden dimintai persetujuan dan persepsinya atas bagaimana mekanisme transparasi terhadap pemegang saham biasanya dilakukan. Tabel 3 menggambarkan persetujan responden yang tinggi terhadap 2 buah pertanyaan mengenai transparasi catatan keuangan, kinerja manajemen, status kepemilikan, dan tata kelola perusahaan.

Tabel 3. Persepsi Responden terhadap Transparansi dan Hubungan dengan Pemegang saham

Pilar 3. Membuat pola informasi yang transparan, terbuka, dan tepat Persetujuan (\%) waktu.

a. Perlakuan yang adil diterima oleh seluruh pemegang saham dan 85,0 perusahaan menyediakan media untuk berkomunikasi dengan dengan pemilik saham

b. Terdapat sebuah mekanisme produktif yang tertuang dalam RUPS 84,3

c. Adanya laporan mengenai kepemilikan keuangan dari setiap pemilik $\quad 78,5$ pertahun

d. Adanya Laporan keuangan yang lengkap dan sistematis

Sumber: Data diolah, 2019

Dewan Komisaris dan Direksi mengambil peran sangat krusial dalam sebuah perusahaan. Dewan-dewan ini dibentuk untuk memonitor fungsi para pemegang saham. Untuk mengetahui persepsi responden terhadap terhadap adanya struktur dewan komisaris dan dewan direksi, maka responden diberi pertanyaan-pertanyaan terkait hal tersebut dalam pilar 4 dan pilar 5 .

Tampak pada Tabel 4, sebagian besar responden menyatakan persetujuan terhadap pembentukan Dewan Komisaris dan Direksi melalui prosedur formal. Dan pada pilar 5, sebagian besar responden menginginkan Dewan Penasehat adalah sebuah posisi independen tanpa merangkap jabatan lainnya.

Tabel 4. Persepsi Responden terhadap Dewan Komisaris dan Direksi

\begin{tabular}{|c|c|}
\hline $\begin{array}{l}\text { Pilar 4. Memiliki kesungguhan dalam berupaya untuk membentuk Dewan } \\
\text { Komisaris }\end{array}$ & Persetujuan (\%) \\
\hline $\begin{array}{l}\text { a. Dewan Penasehat dapat dibentuk oleh perusahaan dengan ukuran lebih kecil } \\
\text { dapat untuk mendukung perkembangan bisnis }\end{array}$ & 78,4 \\
\hline Dewan Komisaris dibentuk melalui prosedur formal & 83,2 \\
\hline $\begin{array}{l}\text { c. Pihak independen seharusnya diajak oleh perusahaan sebagai anggota Dewan } \\
\text { Komisaris tetap }\end{array}$ & 63,8 \\
\hline Program pelatihan harus diberikan kepada anggota-anggota direksi yang baru & 75,2 \\
\hline \multicolumn{2}{|l|}{$\begin{array}{l}\text { Pilar 5. Memberikan arahan yang jelas kepada Dewan Komisaris dalam hal } \\
\text { pengawasan kinerja }\end{array}$} \\
\hline $\begin{array}{l}\text { a. Dewan Komisaris harus mempunyai dukungan dalam menjalankan tugas } \\
\text { utama }\end{array}$ & 83,2 \\
\hline $\begin{array}{l}\text { b. Dewan Komisaris melakukan kegiatan monitoring dan evaluasi terhadap } \\
\text { kinerja manajemen }\end{array}$ & 80,0 \\
\hline Evaluasi kinerja dilakukan secara rutin oleh Dewan Komisaris & 74,9 \\
\hline d. Dewan Penasehat tidak merangkap jabatan operasional dalam perusahaan & 83,7 \\
\hline
\end{tabular}

Sumber: Data diolah, 2019

Dalam menciptakan sebuah lingkungan usaha yang terkendali dengan baik, pedoman GCG seperti yang dikutip oleh Dubai SME merekomendasikan sistematika pembukuan yang kredibel dan terpercaya karena akan mempengaruhi pengendalian internal yang efektif. Tabel 5 yang berisikan pilar 6 dan pilar 7 memperlihatkan persepsi responden terhadap lingkungan pengendalian. Pada pilar 6, responden setuju atas adanya praktik akuntansi yang kredibel serta adanya evaluasi audit eksternal demi menjaga independensi fungsi audit. Pada pilar 7, responden 
menyetujui adanya kegiatan identifikasi resiko bisnis dengan mengunakan jasa akuntan publik yang cenderung formal dalam mengumpulkan data akuntansi mengenai keuangan tapi dirasa kurang bisa memberikan pengaruh kepada UKM yang telah diaudit.

Tabel 5. Persepsi Responden terhadap Lingkungan Pengendalian

\begin{tabular}{llc}
\hline Pilar 6. Auditor eksternal melakukan kewajibannya yaitu mengaudit & Persetujuan (\%) \\
pembukuan & 78,0 \\
\hline a. Adanya praktik akuntan yang kredibel di dalam perusahaan. & 81,2 \\
a. Perusahaan menjaga independensi fungsi audit dan mengevaluasi & \\
efektifitas audit eksternal & 83,0 \\
Pilar 7. Menetapkan konteks draft pengendalian internal dan meninjau \\
$\quad$ ulang resiko secara berkala & 80,0 \\
a. Identifikasi resiko harus dilakukan secara berklaa oleh perusahaan & 78,4 \\
b. Dalam skala besar, perusahaan sudah bisa melaksanakan kegiatan \\
$\quad$ pengendalian dalam cakupan yang besar \\
c. Perusahaan melakukan audit internal secara berkala & \\
\hline
\end{tabular}

Sumber: Data diolah, 2019

Untuk menunjukkan persepsi responden terhadap pemangku kepentingan dalam kelompok pegawai, pemasok, kreditor, pemerintah, masyarakat, dan lingkungan serta pemangku kepentingan dalam perusahaan tergambar dalam Tabel 6 .

Tabel 6. Persepsi Responden terhadap Hubungan dengan Pemangku Kepentingan

\begin{tabular}{llc}
\hline Pilar 8. Mengenali kebutuhan pemangku kepentingan & Persentase (\%) \\
\hline a. $\quad \begin{array}{l}\text { Dalam proses pengambilan keputusan, semua pemangku kepentingan } \\
\text { harus mengambil peran demi keberlanjutan perusahaan }\end{array}$ & 83,3 \\
b. $\quad \begin{array}{l}\text { Hubungan antara pemangku kepentingan harus punya indikator jelas yang } \\
\text { bisa diukur dan dimonitor }\end{array}$ & 82,9 \\
\hline
\end{tabular}

Sumber: Data diolah, 2019

Tabel 6 menunjukkan persetujuan responden atas adanya kebijakan yang mengatur pengambilan keputusan oleh para pemangku kepentingan. Perusahaan sebaiknya mempunyai formula mengenai kebijakan yang sudah menggambarkan visi dan misi perusahaan. Para responden juga mulai menyadari bahwa kinerja manajemen yang bisa diukur dan dimonitor memiliki nilai penting.

Tata kelola keluarga atau Family Governance ini menyangkut kebijakan-kebijakan yang mengatur hubungan keluarga didalam bisnis diantaranya seperti, persyaratan-persyaratan untuk menduduki jabatan tertentu, siapa yang berhak mengelola perusahaan, dan bagaimana cara keuntungan dibagi dan pendistribusian kepada sesama anggota dan lain sebagainya. Sebuah penelitian berpendapat bahwa perusahaan UKM lebih memiliki kecendrungan mempraktekkan sistem SDM secara informal dibanding dengan usaha skala besar (Palupijati, 2013).

Tabel 7. Persepsi Responden terhadap Family Governance

\begin{tabular}{lcc}
\hline Pihak 9. Formulasi kerangka yang menjelaskan hubungan keluarga dan & Persetujuan (\%) \\
bisnis & 75,0 \\
\hline a. & Perusahaan memiliki aturan dan kebijakan terkait tentang keluarga & 65,1 \\
b. & Perusahaan memiliki tata kelola keluarga untuk memfasilitasi komunikasi. &
\end{tabular}

Sumber: Data diolah, 2019

Tabel 7 menunjukkan persepsi responden terhadap family governance pada perusahaan mereka. Responden memberikan persetujuan yang tinggi atas diperlukannya sebuah kebijakan yang mengatur hubungan bisnis keluarga dengan visi dan misi perusahaan. Hal ini bertujuan untuk mengurangi kemungkinan dampak permasalahan keluarga yang akan timbul untuk generasi 
penerus. Kemudian responden juga memberikan persetujuan yang tinggi terhadap adanya komunikasi dan koordinasi yang efektif yang berguna untuk kepentingan hubungan keluarga didalam bisnis.

\section{SIMPULAN DAN REKOMENDASI}

Dari hasil peneltian dan pembahasan yang telah dijabarkan diatas, hasil survei terhadap responden menemukan adanya 2 (dua) pola kecenderungan UKM dalam implementasi GCG pada perusahaan. Pertama, perusahaan skala kecil cenderung lebih mengerahkan strategi bertahan (survive) daripada melaksanakan prinsip GCG. Kedua, untuk perusahaan skala menengah dan besar memiliki kecenderungan yang besar untuk melaksanakan prinsip GCG, karena didukung adanya implementasi praktik manajerial yang formal.

Penelitian ini menggunakan usulan pilar-pilar GCG berdasarkan pedoman GCG yang sebaiknya diimplementasikan oleh UKM di Kota Padang agar UKM di Kota Padang bisa memiliki parktik manajerial yang sesuai dengan prinsip GCG. Pada penelitian ini juga ditemukan, agar mekanisme GCG bisa berjalan secara maksimal perusahaan sebaiknya memodifikasi beberapa aspek yang terkait dengan keseluruhan pilar. Modifikasi yang diperlukan diantaranya: pertama, perusahaan UKM harus bisa membedakan status badan hukum baik secara perorangan atau sudah berbadan Perseroan Terbatas (PT) melalui pedoman perundang-undangan tentang badan hukum di Indonesia. Kedua, perusahaan UKM di Kota Padang yang memiliki status perorangan dan CV perlu memberdayakan seseorang untuk dijadikan Dewan Penasehat atau Sekutu Komanditer dalam mendukung kebertahanan dan keberlanjutan perusahaan tersebut. Ketiga, sistem family governance atau tata kelola keluarga dalam perusahaan harus memiliki maintenance yang baik untuk mengoptimalkan potensi SDM perusahaan. Penelitian ini masih memiliki potensi kelemahan karena terbatasnya jumlah sampel yang digunakan, sehingga penelitian lebih mendalam perlu dilakukan untuk mendapat masukan dari pelaku UKM dalam rangka menggali informasi lebih dalam sehingga bisa mendapatkan hasil penelitian yang lebih valid.

\section{DAFTAR PUSTAKA}

Amoateng, A. K., Osei, K. T., Ofori, A., \& Gyabaa, E. N. (2017). Empirical Study on The Impact of Corporate Governance Practices On Performance: Evidence from SMEs in An Emerging Economy. European Journal of Accounting Auditing and Finance Research, 5(8), 50-61. https://www.eajournals.org/journals/european-journal-of-accountingauditing-and finance-research-ejaafr/vol-5-issue-8-august-2017/empirical-study - impactcorporate - governance-practices-performance-evidence-smes-emerging-economy/

Department of Economic Development. (2013). The State Of Small \& Medium Enterprises (Smes) In Dubai. Retrieved from www.sme.ae. http://www.sme.ae/arabic/Pages/default.aspx

Dinas UMKM Sumbar. (2017). Data Usaha Mikro Kecil dan Menengah Provinsi Sumatera Barat Posisi Desember 2017. Padang: Pemprov Sumatera Barat.

Dwiridotjahjono, J. (2009). Penerapan Good Corporate Governance: Manfaat dan Tantangan serta Kesempatan bagi Perusahaan Publik di Indonesia. Jurnal Administrasi Bisnis, 5(2). http://journal.unpar.ac.id/index.php/JurnalAdministrasiBisnis/article/view/2108/1918

Elmagrhi, M. H., Ntim, C. G., Crossley, R. M., Malagila, J. K., Fosu, S., \& Vu, T. V. (2017). Corporate governance and dividend pay-out policy in UK listed SMEs. International Journal of Accounting \& Information Management. https://doi.org/10.1108/ijaim-022017-0020 
Fatimah, F., Mardani, R. M., \& Wahono, B. (2019). Pengaruh Good Corporate Governance terhadap Nilai Perusahaan dengan Kinerja Keuangan sebagai Variabel Intervening (Studi Kasus Pada Perusahaan Manufaktur Sektor Barang). Jurnal Ilmiah Riset Manajemen, 8(15). http://riset.unisma.ac.id/index.php/jrm/article/view/4449/3977

FCGI. (2011). Forum for Corporate Governance in Indonesia. Retrieved from 2011 website: http://fcgi.or.id

Jaswadi, J. (2016). Analisis Tingkat Implementasi Good Corporate Governance pada Usaha Kecil dan Menengah. Jurnal Siasat Bisnis, 20(2), 161-180. https://doi.org/10.20885/jsb.vol20.iss2.art5

Kurniawati, S. L., Purnamasari, L., \& Puspitaningrum, T. (2015). Penerapan Good Corporate Governance (Tata Kelola) pada Usaha Kecil Menengah (UKM) di Surabaya dalam Menghadapi MEA 2015. http://eprints.perbanas.ac.id/id/eprint/2974

Mailisa, Y., Hendri, M. I., \& Fauzan, R. (2016). Pengaruh Iklim Organisasi dan Kemampuan Kerja terhadap Komitmen Organisasional dan Dampaknya pada Kinerja Pegawai DISPERINDAGKOP dan UKM Kota Pontianak. Jurnal Ekonomi Bisnis dan Kewirausahaan (JEBIK), 5(3), 198-215. http://dx.doi.org/10.26418/jebik.v5i3.19081

Ntim, C. G. (2018). Defining Corporate Governance: Shareholder versus Stakeholder Models, in "Global Encyclopedia of Public Administration, Public Policy and Governance", Springer, USA. https://ssrn.com/abstract=3096612

Palupijati, S. (2013). Tata Kelola pada UKM: Perbandingan Penerapan pada Bisnis Keluarga dengan Bisnis Non-Keluarga. Universitas Gadjah Mada. http://etd.repository.ugm.ac.id/home/detail_pencarian/65841\#filepdf

Salim, A. (2018). Perbedaan Kinerja Keuangan Perbankan Sebelum dan Sesudah Penerapan Good Corporate Governance (GCG) Studi Kasus Pada Bank Syariah Mandiri. Ekomadania: Journal of Islamic Economic and Social, 1(2), 149-176. http://ejournal.kopertais4.or.id/madura/index.php/ekomadania/article/ article/view/3179

Sukmadilaga, C., Pratama, A., \& Mulyani, S. (2015). Good Governance Implementation in Public Sector: Exploratory Analysis of Government Financial Statements Disclosures Across ASEAN Countries. Procedia - Social and Behavioral Sciences. https://doi.org/10.1016/j.sbspro.2015.11.068.

Susilo, Y. S. (2010). Peran perbankan dalam pembiayaan UMKM di Provinsi DIY. Jurnal Keuangan dan Perbankan, 14(3), 467-478. http://jurnal.unmer.ac.id/index.php/jkdp/ article/view/988/631

Tjondro, D., \& Wilopo, R. (2011). Pengaruh Good Corporate Governance (GCG) terhadap Profitabilitas dan Kinerja Saham Perusahaan Perbankan yang Tercatat di Bursa Efek Indonesia. Journal of Business \& Banking (JBB), 1(1), 1-14. https://journal.perbanas.ac.id/index.php/jbb/article/download/148/103

Wardhana, D. Y. (2018). Good Corporate Governance Practices in Family Business: A Case Study in Indonesia. Petra International Journal of Business Studies, 1(1), 35-44. https://doi.org/10.9744/ijbs.1.1.35-44

Wijaya, H., \& Abdullah, J. (2016). Analisis Pelaksanaan Good Corporate Governance (GCG) pada UKM di Malang Raya. Jurnal Mahasiswa Akuntansi Manajemen, 2(2). http://jmam.polinema.ac.id/index.php/jmam/article/view/39 